\title{
家庭排水処理 生物膜法
}

生物膜法には，散水ろ床，回転门板，接触曝気法な ごがあるが，ここでは家庭排水処理の浄化槽に多く用 いられている接触曝気法（浸漬乃床法）の今後の展望 などについて若干の考え方を述べる。

散水乃床法や接触曝気法については，19世紀末ょり 実験が行われ，活性污泥法よりも古い歴史を持ってい るが, 現在, 日本の公共下水道の処理場にみられるご とく，これまで活性污泥法が下水処理の主流となって きた．1960年代に入って接触曝気法の研究が始められ， 1970年以降，お屯に浄化槽の分野で急速に技術的な発 展をみるにいたった。これは公共用水域での水質の亜 化と家庭排水の処理を十分に行わなければならないと いう要求がその背景となっている゙”.

浄化槽の処理技術として必要な要素は，維持管理が 簡単である，狭い場所でも設置できる，装置の費用や 維持経費が高すぎない，十分な処理性能を安定して維 持できる，などがあげられ，接触曝気法はこれらの要 求にかなった技術として発達してきた。すなわち，接 触曝気法は，処理水の B O D 5 濃度が $60 \mathrm{ppm}$ あるい は90ppm 程度と活性污泥法より性能は少っているが, コンパクトで人手がいらない処理方法であるという一. 般的な評価となるが，これらはこれまでの浄化槽とい う枠の中での評価といえる。

しかし，近年，家庭排水とくに雑排水が水域の活濁 の原因として問題となってきている．家庭排水の処理 を行うには，下水道を建設する事が最む確実な方法で あるが，下水道を建設するにはかなりの年月と多額の 経費が必要である。したがって，早急に家庭排水の処 理を必要としている地域については，下水道が建設さ れるまでの間に, 必要な雑排水処理対策をとる必要が ある。その対策としては，1）戸別合併処理浄化槽，

2 ）雑排水処理装置，3）農村下水道・コミュニティ

* 龍谷大学理工学部助教授

Fumihiko JIKU
プラントなどがあり，これらの処理法には接触曝気法 が多く用いられている。

1 ）戸別合併処理浄化槽では，嫌気ろ床処理と接触 曝気処理を組み合わせるという新しい処理技術が採用 され，処理水質もB O D 20ppm 以下と下水道と同等 の処理レベルとなっており，生物膜法の新しい展開と 言える。この生物膜法の発展は，環境に関する技術， とくに排水処理技術の常であるが，法的な規制の強化 あるいは社会的な要請に基づいて，新たな技術の枠組 みが搪大する例である（技術的な裏付けがあってはじ めて, 法的規制が可能となる側面屯ある).

これまで接触曝気法の技術に関しては，乃材の材質・ 形状, 曝気方法, 槽への流入・流出の方法などさまざ まな検討，開発がなされ，技術的な蓄積が既になされ てきており，今後は嫌気ろ床法に関する技術の蓄積が 必要であろう。ろ床への污泥の堆積による有効容量の 低下やろ床槽の清掃が難しい事などに対する改善が望 まれる。

今後の技術的な課題としては, 窒素, リンの処理が あり, 窒素の処理については，嫌気ろ床槽への処理水 の返送などの技術開発がなされているが，リンの処理 については, 物理化学的な処理を含め, 実用化が急が れる。また，生物膜法の課題とは言えないが，浄化槽 の課題としては排出污泥の処理方法・体制がある.

また，浄化槽は日本国内の他，開発途上国なよ゙で水 質污濁が問題が起こっている地域における処理対策と して用いることができ，異なった条件下において生物 膜法が利用される可能性もある。

2 ）雑排水専用処理装置については, 沈殿槽や接触 曝気槽が用いられている，沈殿槽では，接触ろ材を充 填したものなよ゙が多く，生物膜法の一種と考えられる が，法律的に設置を強制できるものではなく，費用む 個人的な負担となることが多いため，あまり普及して いるとは言えない，その処理技術，容量，価格はさま 
ざまであり，メーカーも大小さまざまである，処理性 能も十分とは言えないものも多く，その評価は高くな い.しかし, 湖沼周辺など窒素, リンの除去が必要な 地域で，し尿くみ取りを戸別合併処理浄化槽に変える と, BODの処理の点では良いが, 窒素, リンの排出 量は増加する可能性むあり，このような場合には性能 の良い雑排水処理装置を設置する方が望ましい. また, 比較的早い時期に下水道が建設される地域などでは, 下水道までのつなぎとして, 雑排水処理装置を早急に 設置することが望まれる，そのためには，雑排水処理 に適した接触ろ材の開発の他, 個々の処理装置の性能 を公にしたり，標準的な処理装置を推薦したり，より 積極的な対応が必要である。

3 ）農村下水道やコミュニティプラントなどの集合 的な処理施設においても生物膜法が多く用いられてい るが, 戸別合併処理浄化槽と同様, 今後は窒素, リン の処理や污泥処理が課題であろう.ただし, 処理の規 模が大きいため，技術的にあるいは経済的にその対策 は比較的とり易いものと考えられる。しかし，嫌気ろ 床槽への処理水の返送による窒素の除去においても， 安定して効率の高い処理を維持するには，今後もその 維持管理技術の蓄積が重要であろう。また, 生物膜法 は活性污泥法に比べると自動制御による管理が行い易 いと考えられるため, 流入水量, 曝気槽の D O 值など によって曝気量をコントロールしたり, 曝気槽の濁度 によって逆洗を行ったり，マイコンを利用した新しい 管理技術を開発することが可能であろう．水質が良好 になってきたために起こってきた現象と考えられるが，
サカマキガイやミズムシなど生物の出現でろ材の生物 膜がきれいになくなってしまう事例などが出てきてお り，このような新しい事態への対応も必要である.

以上のごとく, 家庭排水の処理については, 雑排水 が未処理で放流される状態を改善し，何らかの処理装 置を設置することが原則であるが，これらの処理装置 を設置しても窒素，リンの処理については不十分之な る可能性もある。この場合には河川での浄化に頼らざ るを得ない. 少しでも河川の浄化力を高めるためには, コンクリートの水路となっている身の回りの小川を以 前の様な生物相の豊かな状況に戻したり，こまめに小 川の泥掃除をしたりということが必要である。また， 可能であれば，接触ろ材を河川に浸漬したり，河川水 を分流して接触ろ材の水路を通して浄化を図るいわゆ る河川浄化も検討していかざるを得ないであろう。各 地で接触ろ材，碟，木炭などを用いて河川浄化が検討 されているが, 技術的に確立されてきたとは言い難い. この原因として, 河川浄化においては, 下水の接触曝 気処理における沈殿槽にあたるものが設置されていな いことが一因であろうと思われる。すなわち，増加し た生物膜を排除することが必要で，沈殿部を設けるか 適当な間隔でろ材を取り替えることなどによって，技 術的確立を図る必要があろう。この他, 池の浄化や湖 岸や内湾の浄化などに生物膜法を用いて, 直接的な浄化 を行う検討も今後必要になってくるのではないだろうか.

\section{参 考 文 献}

1 ) 須藤隆一他 : 生物膜法, p.222, 産業用水調査会 (1980)

\section{海外環境情報}

\section{水河期における火山活動と気象}

Exploding into an Ice Age

地球温暖化と火山について研究している地質学者ら はこのほよ゙，約 2 百万年前に発生した水河期と同じ時 期に大規模な火山活動があり，この火山活動が地球規 模の冷却化を促進したとする研究結果を発表した。こ の研究を行った米国 New York 大学の Michael Rampino 氏と Hawaii 大学の Stephen Self 氏によ れば，新しい数学モデルを用いることによって，7万 3500年前にインドネシアのスマトラ諸島で発生した Toba 火山の噴火で10億トンもの火山灰が地球大気に 放出され，その灰が高度27〜37kmにも及んだと仮定し た上で気象変化に関するシミュレーションを行ったと いう。この解析結果によると, この火山灰は地球上に 広がり，太陽光を遮ったため火山噴火後少なくとも 2 〜 3 年間は地球の気温が平均 3〜 5 度 C 低下したと推 定されるという。そして，この大規模な気象変化が本 格的な水河期の発生を加速する要因になったとしてい る.さらに Rampino氏らは，この火山活動と地球冷 却化に関する動特性はフィードバック効果を含んでお り, 水河期の本格的到来により, 海洋の水位が低下し, その結果 Toba 火山の活動は鎮静化へ向かったとし ている

Science News Vol.142, No.13, September 26, 1992

（科学技術国際交流センター発行 MOVEMENT 第 8 号より転載） 